\title{
THE RELATIONSHIP BETWEEN EXCHANGE RATE AND EXPORTS IN ROMANIA USING A VECTOR AUTOREGRESSIVE MODEL
}

\author{
Carmen Sandu ${ }^{l}$ \\ Nicolae Ghiba ${ }^{2}$
}

\begin{abstract}
In this paper we analyze the exchange rate influence on exports volume in Romania using a vector autoregressive model (VAR). Our analysis, relative to the 2003Q2-2011Q1 period, reflects a negative relationship for the first lag and a positive one in the second lag. Considering the first lag as being significant, an increase of the exchange rate level has effects in decreasing exports volume. Also, according to impulse-response function, a shock in the exchange rate has significant effects on exports after two periods. Variance decomposition shows a weaker influence, less than 10 percent.
\end{abstract}

Key words: exchange rate, volatility, Romanian leu, international trade, depreciation, appreciation.

JEL codes: F31, C32, E31

\section{Introduction}

After the collapse of the Bretton Woods monetary system, which was based on a fixed course, a lot of theoretical and empirical articles examined the relationship between exchange rate volatility and trade flows. The purpose was to identify specific connections regarding the transmission effects of the currency volatility, in the economy. The general idea that prevails in all these works is based on uncertainties concerning the evolution of one currency against another, and their effects on a specific national balance of goods and services.

Romania is a small, open economy that operates in the highly integrated single market of European Union and which had a strong export, import and Gross Domestic Product growth in the period before financial crisis.

Using econometric methods, our research tries to identify the nature of the connection between exchange rate and exports, in Romania. We used autoregressive vectors for the real exchange rate between Romanian Leu and euro and exports volume in millions euro in 2003Q22011Q1 period. The same methodology is used by Boug and Fagereng on Norwegian exports and their empirical findings indicate a weak connection (Boug and Fagereng, 2010). Other studies on the relationship between exchange rate and exports reflect a positive or negative connection that depends on risk preferences, different opportunities in the international capital markets and trade time horizon (Viane and Vries, 1992; Sercu, 1992).

Our paper is organized in four parts: in the firs part we analyze the literature review regarding the relationship between the exchange rate and exports volume (especially, the situation of other theoretical or empirical approaches concerning the relationship between exports and exchange rate in Romania), in the second part we present exports and real exchange rate data and we develop the autoregressive vector methodology, in the third part we interpret our main conclusion on the obtained results, and finally we reflect detailed conclusions compared to previous studies. The main concepts used are the exports volume and exchange rate volatility, the nature of the relationship between variables and the vector autoregressive methodology.

\footnotetext{
1 University “Alexandru Ioan Cuza”, Iaşi, Romania,e-mail: sandu_carmen@yahoo.com

2 University"Alexandru Ioan Cuza" of Iaşi, Romania, e-mail: ghiba.nicolae@yahoo.com
} 


\section{Literature review}

Hall et al. consider that states economic development influence the obtained results by using econometric methods. Compared to superior developed economies, emerging countries react more rapidly so that exchange rate volatility influences the real economy, in short time. An emerging economy (similar to the one in Romania), compared to a developed one, is more fragile to shocks, due to inferior efficiency mechanisms and reduced financial resources available (Hall et al., 2010).

The elasticity of the relationship between exchange rate and exports depends on the analyzed region. In Eastern Asia, international trade is discouraged by exchange rate volatility, which is stronger than in Europe (Kazunobu and Fukunari, 2009).

During the recent crisis, exchange rate volatility increased caused by serious macroeconomic imbalances. The "contagion effect" determines the Romanian leu, to be more perceptive to the volatility of the other currencies from the Eastern Europe. In the same time, exports volume reduced as a response to a decreasing foreign demand. In this case, the exchange rate has lost a part of its influence in the exports evolution. Some authors consider that national currency depreciation may be a necessarily, on short term incentive for economic recovery (Hall et al., 2010). Different points of view don't agree with this idea and sustain that exchange rate depreciation may have more negative than positive effects (Ripoll-i-Alcon, 2010).

Financial market development influences the exchange rate fluctuations intervals. Under these conditions, volatility has strong implications on international trade if financial market development is lower (Aghion et al., 2009). This idea is developed by Rahman, in 2009, which pays special attention to the position of the partners involved in international trade, concerning currency risk. The same author presents some noteworthy factors when performing an analysis of the relationship between exchange rate and exports: the existence of multinational companies involved in international trade and participants expectations regarding the exchange rate volatility (Rahman and Serletis, 2009).

The main empirical conclusion about the connection between exchange rate and exports volume is presented below (table no. 1).

Table no.1

Main empirical studies on the relationship between exchange rate and exports (Hall, 2010: p.3)

\begin{tabular}{|c|c|c|c|}
\hline $\begin{array}{c}\text { Author/-s, } \\
\text { publication year }\end{array}$ & $\begin{array}{l}\text { Period, } \\
\text { frequency }\end{array}$ & Considered countries & Conclusions (results) \\
\hline Doroodian (1999) & $\begin{array}{l}\text { 1973-1996, } \\
\text { quarterly }\end{array}$ & India, Malaysia, South Korea & Significant negative impact \\
\hline Arize $(2000)$ & $\begin{array}{l}\text { 1973-1996, } \\
\text { quarterly }\end{array}$ & $\begin{array}{l}13 \text { economically weak countries } \\
\text { (SDE): Ecuador, Indonesia, Korea, } \\
\text { Malaysia, Malawi, Mauritius, Mexico, } \\
\text { Morocco, Philippines, Sri Lanka, } \\
\text { Taiwan, Thailand, Tunisia }\end{array}$ & Significant negative impact \\
\hline Sauer, Bohara (2001) & $\begin{array}{l}\text { 1973-1993, } \\
\text { annual }\end{array}$ & $\begin{array}{l}91 \quad \text { countries: } 22 \text { economically } \\
\text { developed, } 25 \text { Latin countries, } 25 \\
\text { African countries, } 12 \text { Asian countries } \\
\text { and other } 17 \text { states }\end{array}$ & $\begin{array}{l}\text { Significant negative impact } \\
\text { for Latin America and African } \\
\text { countries }\end{array}$ \\
\hline Doganlar (2002) & $\begin{array}{l}\text { 1980-1996, } \\
\text { quarterly }\end{array}$ & $\begin{array}{l}\text { Turkey, Korea, Malaysia, Indonesia, } \\
\text { Pakistan }\end{array}$ & Significant negative impact \\
\hline Rahmatszah (2002) & $\begin{array}{l}\text { 1970-1997, } \\
\text { quarterly } \\
\text { bilateral } \\
\text { exports and } \\
\text { imports } \\
\text { between the } \\
\text { U.S. and Japan }\end{array}$ & Thailand & $\begin{array}{l}\text { Significant negative impact } \\
\text { for Japanese exports and } \\
\text { inconclusive results about } \\
\text { exports to USA }\end{array}$ \\
\hline
\end{tabular}




\begin{tabular}{|c|c|c|c|}
\hline $\begin{array}{l}\text { Esquivel, } \\
(2002)\end{array}$ & $\begin{array}{l}\text { 1973-1998, } \\
\text { annual }\end{array}$ & $\begin{array}{l}\text { G3 (Germany, Japan, USA), } 40 \\
\text { countries in Asia, Africa, Europe and } \\
\text { Latin America }\end{array}$ & $\begin{array}{l}\text { Currencies volatility from G3 } \\
\text { countries has significant } \\
\text { negative impact on emerging } \\
\text { countries }\end{array}$ \\
\hline $\begin{array}{l}\text { Bahmani-Oskooee } \\
(2002)\end{array}$ & $\begin{array}{l}\text { 1974-1994, } \\
\text { quarterly }\end{array}$ & Iran & Significant negative impact \\
\hline $\begin{array}{l}\text { Arize, Malindretos and } \\
\text { Kasighatla (2003) }\end{array}$ & $\begin{array}{l}\text { 1973-1996, } \\
\text { quarterly }\end{array}$ & $\begin{array}{l}\text { Burkina Faso, Colombia, Costa Rica, } \\
\text { Jordan, Kenya, Korea, Myanmar, } \\
\text { Pakistan, South Africa, Venezuela }\end{array}$ & Significant negative impact \\
\hline Poon (2005) & $\begin{array}{l}\text { 1973-1997, } \\
\text { quarterly }\end{array}$ & $\begin{array}{l}\text { Indonesia, Japan, South Korea, } \\
\text { Singapore, Thailand }\end{array}$ & $\begin{array}{l}\text { Significant negative impact, } \\
\text { excepting Thailand }- \text { a } \\
\text { positive impact }\end{array}$ \\
\hline Rey (2006) & $\begin{array}{l}\text { 1970-2002, } \\
\text { quarterly }\end{array}$ & $\begin{array}{l}\text { Algeria, Egypt, Tunisia, Turkey, Israel, } \\
\text { Morocco (exports to EU countries) }\end{array}$ & $\begin{array}{l}\text { Inverse relationship to } \\
\text { Algeria, Egypt, Tunisia, } \\
\text { Turkey and a positive } \\
\text { relationship to Israel and } \\
\text { Morocco }\end{array}$ \\
\hline Wang, Barret (2007) & $\begin{array}{l}\text { 1989-1998, } \\
\text { monthly }\end{array}$ & Taiwan & $\begin{array}{l}\text { Volatility affects only the } \\
\text { trade in agricultural products }\end{array}$ \\
\hline Baak (2007) & $\begin{array}{l}\text { 1981-2004, } \\
\text { quarterly }\end{array}$ & $\begin{array}{l}\text { Hong Kong, South Korea, Singapore } \\
\text { and Thailand }\end{array}$ & $\begin{array}{l}\text { Volatility affects only the } \\
\text { trade in agricultural products }\end{array}$ \\
\hline Tenreyro (2007) & $\begin{array}{l}\text { 1970-1997, } \\
\text { annual }\end{array}$ & 87 countries, bilateral exports & $\begin{array}{l}\text { Volatility has no effect on } \\
\text { exports }\end{array}$ \\
\hline Arize (2008) & $\begin{array}{l}\text { 1973-2004, } \\
\text { quarterly }\end{array}$ & $\begin{array}{l}\text { Bolivia, Colombia, Costa Rica, } \\
\text { Dominican Republic, } \\
\text { Honduras, Peru, Venezuela }\end{array}$ & $\begin{array}{l}\text { Significant negative impact of } \\
\text { volatility in short and long } \\
\text { term in all countries }\end{array}$ \\
\hline $\begin{array}{l}\text { Egert, } \quad \text { Morales- } \\
\text { Zumaquero (2010) }\end{array}$ & $\begin{array}{l}1993-2004, \\
\text { annual and } \\
\text { monthly }\end{array}$ & $\begin{array}{l}\text { Bulgaria, Croatia, Czech Republic, } \\
\text { Hungary, Poland, Romania, Slovakia, } \\
\text { Slovenia, Russia, Ukraine }\end{array}$ & $\begin{array}{l}\text { Slovenia, Russia, Romania: } \\
\text { weak connection; for the other } \\
\text { countries considered a strong } \\
\text { negative impact }\end{array}$ \\
\hline
\end{tabular}

Exchange rate volatility impact on Romanian trade was analyzed considering the group of countries of Central and Eastern Europe. Ferto and Fogarasi (2011) explore the effects of exchange rate and institutional quality on international trade between 1999 and 2008 and their findings show a negative relationship between the exchange rate and agricultural export in the Central Europe, including Romania. Another study on Romanian and Bulgarian example reflects an insignificant impact on export development of the real exchange rate appreciation (Penkova-Pearson, 2011).

\section{Data and methodology}

Using VAR modeling, for 2003 Q2-2011 Q1 period, we estimate a connection between real exchange rate EUR/RON (CSR) and exports volume (EXPORTURI). We selected this period, on account of using euro as reference currency in Romania, in the context of the adoption of the single currency in 2015. Since April 2003, the National Romanian Statistics Institute also refers to developments in trade with Euro as reference currency. We used quarterly and logarithmic expressed series in order to avoid eventual heteroscedasticity problems. The real exchange rate is obtained by multiplying the nominal exchange rate (CS) with the ratio between domestic and foreign price index.

The methodology is based on the lagged values of both variables and it is used for the analysis of multivariate time series. Hence, the VAR model is useful for describing the exports' behavior under exchange rate influence. 


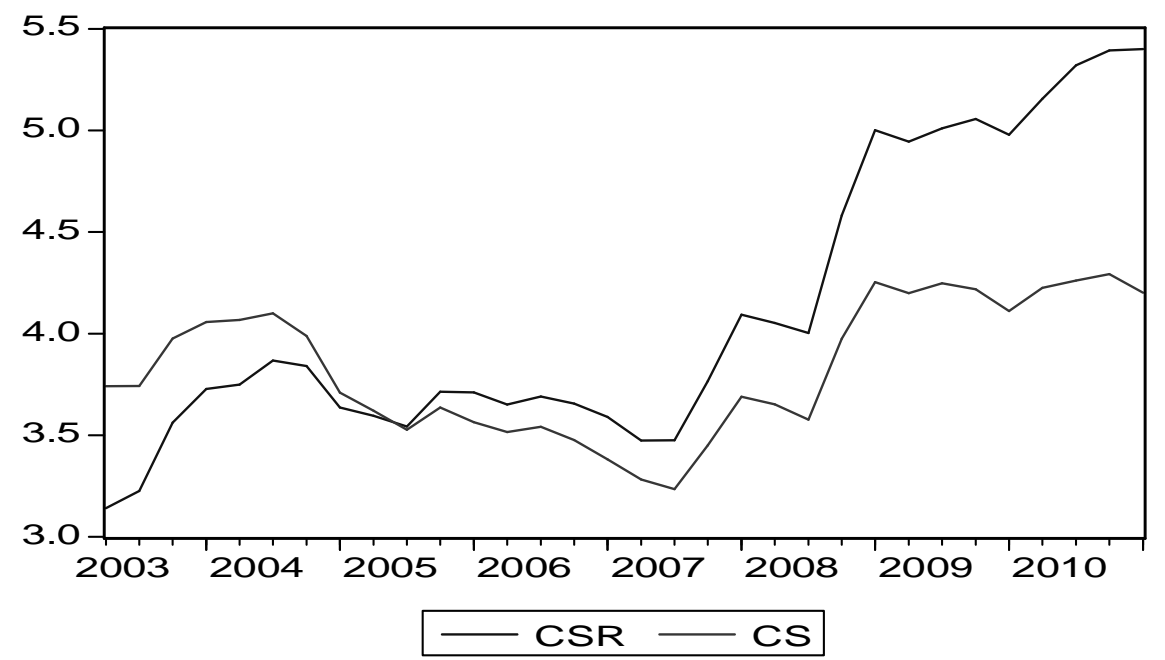

Fig. no. 1. - The evolution of nominal (CS) and real exchange (CSR) rate between euro and Romanian new leu during 2003(Q2)-2011(Q1) period

Source: Data provided by the National Bank of Romania regarding the nominal exchange rate (CS) and deflated with inflation in Romania (Romanian National Institute of Statistics) and inflation in Eurozone (Eurostat) in order to obtain the real exchange rate (CSR)

The real exchange rate in Romania is superior to the nominal rate due to a higher domestic inflation rate, compared with the Euro zone (graphic no. 1).

On the other side, the Romanian exports volume decreased during crisis (after 2008) and then increased again on account of successful international brands as Dacia (a national low-priced car built by Renault). In 2006, we observe a rapid decrease as a response to the Romanian leu depreciation (graphic no. 2).

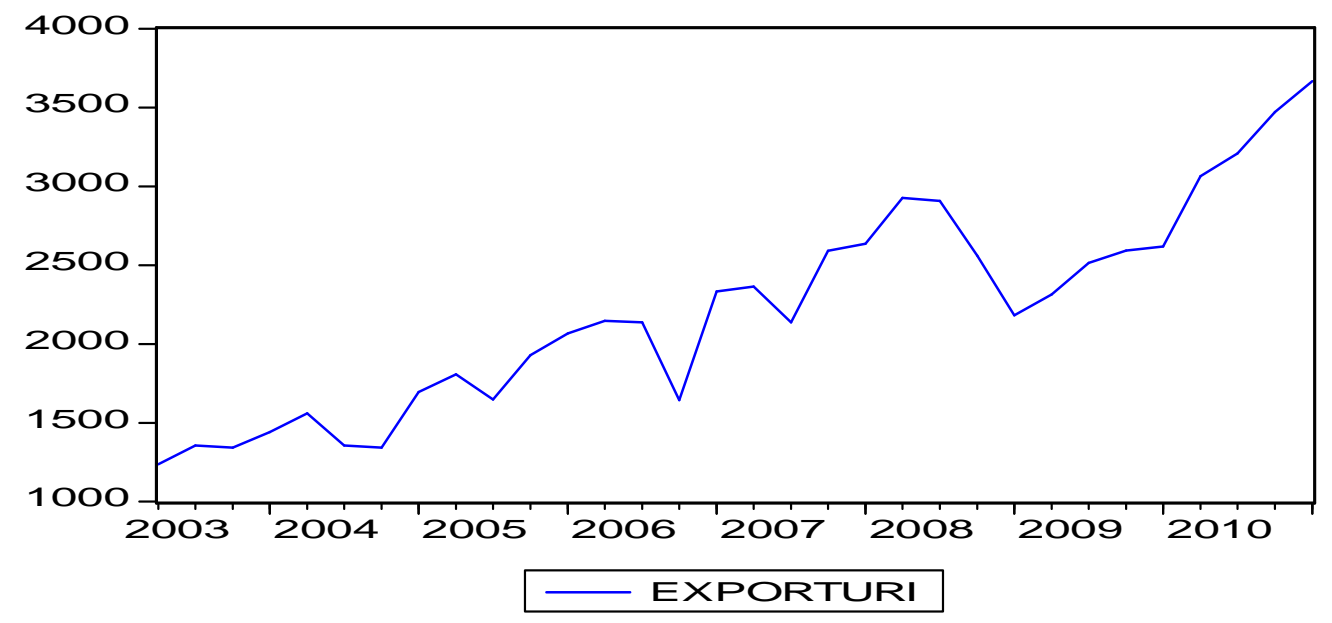

Fig. no. 2. - The exports volume (EXPORTURI) in Romania during 2003(Q2)-2011(Q1) period in millions euro

Source: Data provided by National Bank of Romania (Interactive Database)

After testing variables stationarity, we estimate the impulse response-function and variance decomposition. 


\section{Results and discussion}

Using augmented Dickey Fuller and Phillips Perron stationarity tests we find a unit root presence in level. After we made the first difference, we observed that the exchange rate is stationary (table no.2).

Table no. 2

Exchange rate stationarity tests

\begin{tabular}{|l|l|l|l|}
\hline Stationarity test & Level/First difference & t-statistic & Prob. \\
\hline ADF & Level & 0.201187 & 0.9683 \\
\cline { 2 - 4 } & First difference & -4.014379 & 0.0043 \\
\hline \multirow{2}{*}{ PP } & Level & 0.053724 & 0.9566 \\
\cline { 2 - 4 } & First difference & -3.907190 & 0.0056 \\
\hline
\end{tabular}

The results are similar for the second variable - exports volume (table no. 3).

Table no.3

Exports volume stationarity tests

\begin{tabular}{|l|l|l|l|}
\hline Stationarity test & Level/First difference & t-statistic & Prob. \\
\hline ADF & Level & -0.398052 & 0.8976 \\
\cline { 2 - 4 } & First difference & -6.081640 & 0.0000 \\
\hline \multirow{2}{*}{ PP } & Level & -0.398052 & 0.8976 \\
\cline { 2 - 4 } & First difference & -6.091914 & 0.0000 \\
\hline
\end{tabular}

Using stationarity results we conclude that both used variables are stationary - an eventual shock on them is temporary. Their evolution varies around a mean value and the condition required for further analysis is met.

After testing lag relevance, we found a more relevant relationship in the first one. For the first lag, an increase in the exchange rate level (equivalent with national currency depreciation) leads to a decrease in exports volume. On the other hand, depreciation in the second lag has obviously effects on exports which are increasing, but the relevance is lower compared to the first case. Considering the lag relevance (tested through Schwartz criterion), we suppose a negative relationship between real exchange rate and exports volume statistically significant, as table no. 4 reflects:

Table no.4

Vector Autoregression Estimates

\begin{tabular}{|l|c|}
\hline \multirow{4}{*}{ L_EXPORTURI(-1) } & L_EXPORTURI \\
\cline { 2 - 2 } & 0.657143 \\
\cline { 2 - 2 } & {$[0.19591)$} \\
\hline \multirow{5}{*}{ L_EXPORTURI(-2) } & {$[3.35427]$} \\
\cline { 2 - 2 } & 0.187326 \\
\hline \multirow{5}{*}{ L_CSR(-1) } & {$[0.19768)$} \\
\hline & $-0.94760]$ \\
\cline { 2 - 2 } L_CSR(-2) & $(0.172533$ \\
\cline { 2 - 2 } & {$[-1.96260]$} \\
\cline { 2 - 2 } C & 0.606275 \\
\cline { 2 - 2 } & $(0.55071)$ \\
\hline R-squared & {$[1.10090]$} \\
\cline { 2 - 2 } & 0.872313 \\
\cline { 2 - 2 } & $(0.70565)$ \\
\cline { 2 - 2 } & {$[1.23617]$} \\
\hline
\end{tabular}


Our results show that an eventually shock in the exchange rate volatility is noticeable after two periods. The impulse-response function marks the answer of exports to a shock in exchange rate (graphic no.3). The dashed lines enclose intervals of plus or minus two standard errors.

Response to Cholesky One S.D. Innovations \pm 2 S.E.
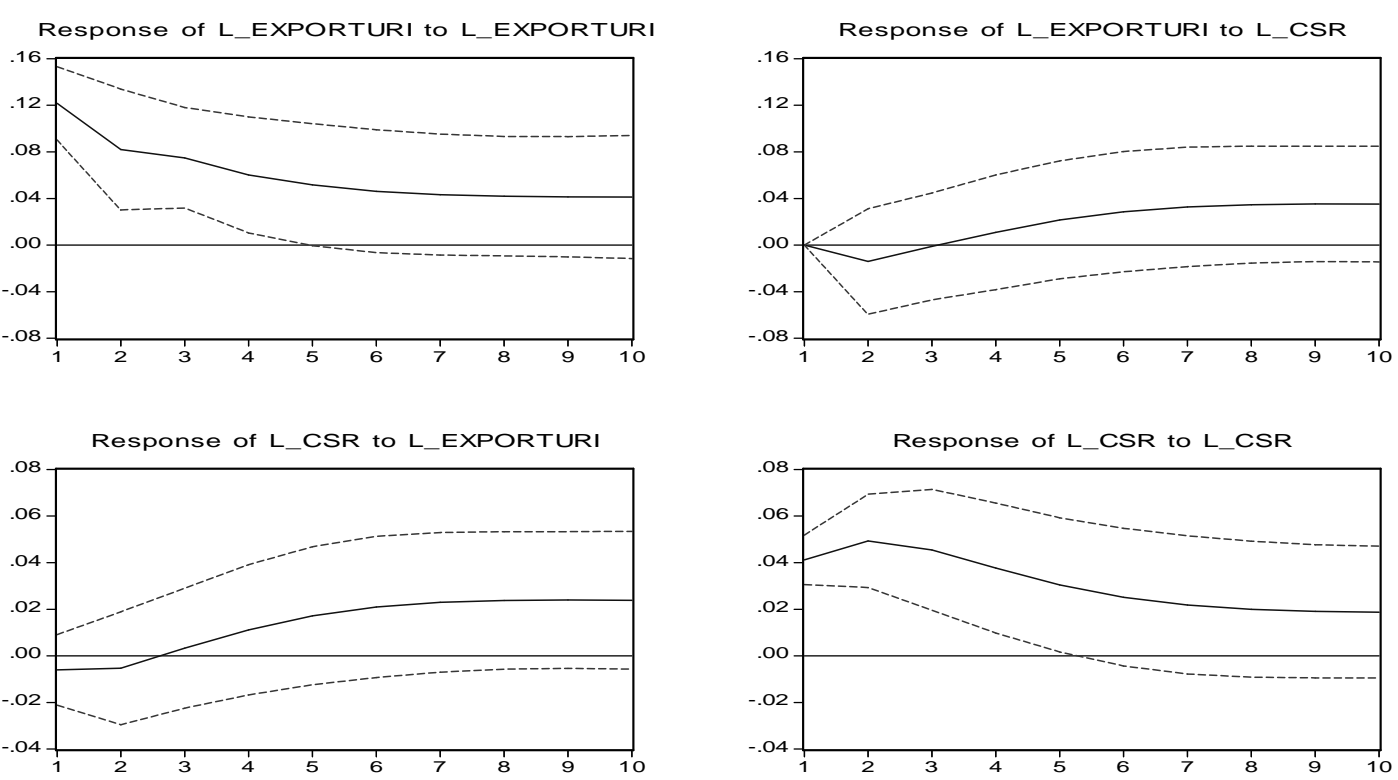

Fig. no. 3. - The impulse-response function

Exchange rate influence on exports is weak, with a percent under $10 \%$. This weakness can be explained by the higher price competitiveness of Romanian products. In the last months, auto industry has been the main engine of domestic international exchanges due to the lowest prices compared with other international competitors. International trade trends have possible influences in exchange rate evolution through their role on market perception. The influence reflects on medium and long-term; information confirmed by variance decomposition. In our search most of the variance comes from the "own-shock", rather than the shock to the other equation.

Variance Decomposition
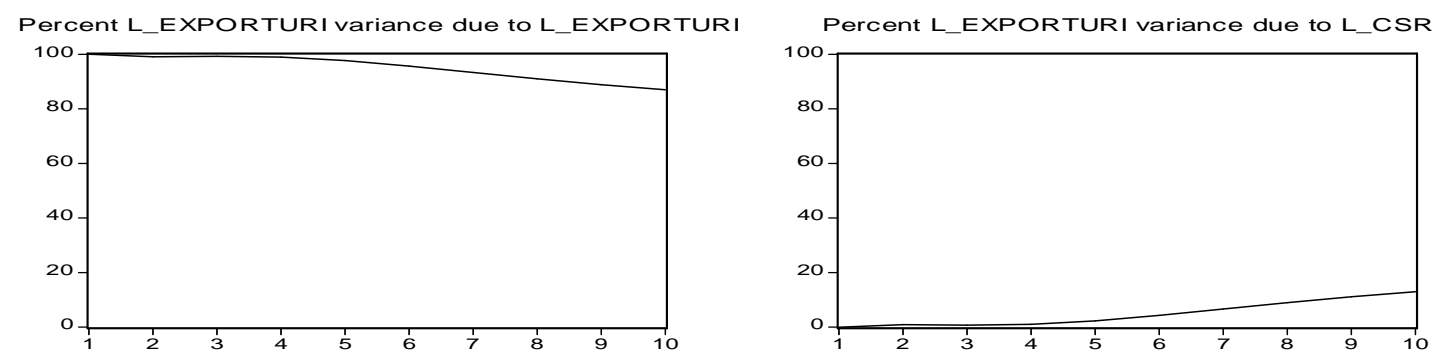

Percent L_CSR variance due to L_EXPORTURI

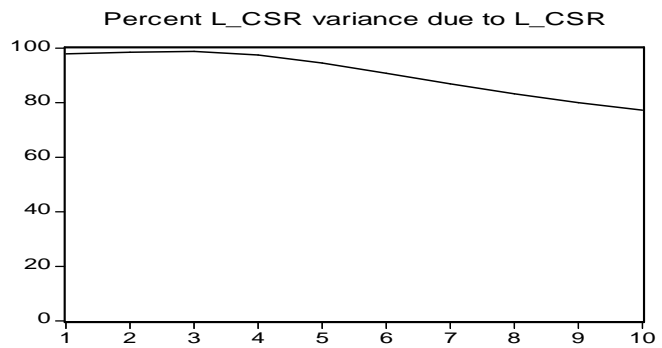

Fig. no. 4. - Variance decomposition 
Asymmetry has a negative value and close to zero that reflects a trend of decreasing error model. Kurtosis coefficient is less than 3: a situation corresponding to a low possibility of occurrence of extreme events that influence in short time export activity in Romania. The model is stable. In addition, specifically tests on residuals show that our results are conclusive.

\section{Conclusion}

Our results show that exchange rate had a weak influence on exports volume, less than 10 percent. In the first lag, there is a negative relationship between variables: the depreciation of Romanian leu determined a decrease in domestic exports. We argue this fact through a lower price level of Romanian products compared to others. On the other side, in the second lag the influence is positive with a superior coefficient, although the relevance in this lag is weaker. The impulseresponse shows the reaction of exports to a shock in error terms. The results reflect an exports response after two periods.

The negative relationship between real exchange rate and exports volume in Romania, significant for the first lag, is similar with the results obtained by Ferto and Fogarasi (2011), even if they consider just the agricultural goods. Also, we obtained an opposite result from PenkovaPearson (2011), based on a more significant coefficient.

After establishing the connections between variables and highlighting a series of characteristics, this article represents a starting point for the development of a similar analysis on the exchange rate influence on Romanian imports.

\section{Acknowledgments}

This work was partially supported by the by the European Social Fund in Romania, under the responsibility of the Managing Authority for the Sectoral Operational Programme for Human Resources Development 2007-2013 [grant POSDRU/107/1.5/S/78342]

\section{References}

1. Aghion P., Bacchetta P., Ranciere R., Rogoff K., 2009. Exchange Rate Volatility and Productivity Growth: The Role of Financial Development, Journal of Monetary Economics, no.56

2. Boug P., Fagereng A., 2010, Exchange Rate Volatility and Export Performance: A Cointegrated VAR Approach, Applied Economics, Volume 42, Issue 7, pp. 851-864

3. Ferto I., Fogarasi J., 2011. On Trade Impact of Exchange Rate Volatility and Institutional Quality: The Case of Central European Countries, Paper presented at the EAAE 2011 Congress: Change and Uncertainty, Challenges for Agriculture, Food and Natural Resources

4. Hall S., Hondroyiannis G., Swamy P., Tavlas G., Ulan M., 2010. Exchange Rate Volatility and Export Performance: Do Emerging Market Economies Resemble Industrial Countries or other Developing Countries?, Economic Modelling

5. Kazunobu H., Fukunari K., 2009. The Effect of Exchange Rate Volatility on International Trade in East Asia, Journal of The Japanese and International Economies, no. 23

6. Penkova-Pearson E., 2011. Trade, Convergence and Exchange Rate Regime: Evidence from Bulgaria and Romania, Bulagarian National Bank, Discussion Papers, no. 85/2011

7. Rahman S., Serletis A., The Efects of Exchange Rate Uncertainty on Exports, Journal of Macroeconomics, no. 31

8. Ripoll-i-Alcon J., 2010. Trade Integration as a Mechanism of Financial Crisis Prevention", International Atlantic Economic Society

9. Viaene J. M., de Vries C.G., 1992. International Trade and Exchange Rate Volatility, European Economic Review, no. 36, pp. 1311-1321 